\title{
Breast Tuberculosis in Southeast Turkey: Report of 27 Cases
}

\author{
Abdullah C. Tanrikulu ${ }^{a}$ Abdurrahman Abakay ${ }^{a}$ Ozlem Abakay ${ }^{b}$ Murat Kapan ${ }^{c}$ \\ a Department of Chest Diseases, School of Medicine, Dicle University, \\ ${ }^{\mathrm{b}}$ Chest Diseases Hospital, \\ ${ }^{\text {c } D e p a r t m e n t ~ o f ~ G e n e r a l ~ S u r g e r y, ~ S c h o o l ~ o f ~ M e d i c i n e, ~ D i c l e ~ U n i v e r s i t y, ~ D i y a r b a k ı r, ~ T u r k e y ~}$
}

\section{Key Words}

Breast tuberculosis - Dispensary - DOT - Southeast Turkey . Treatment

\section{Summary}

Background: Breast tuberculosis (TB) is a very rare form of TB. Case series on breast TB are scarce. Patients and Methods: The patients with breast TB treated between 2004 and 2008 at our hospital were retrospectively investigated. Results: All patients were female (mean age 31.5 \pm 8.4 years). All but 1 patient were new cases. Patients presented with swelling of the breast $(48.1 \%)$, mass and fluctuation (each, $40.7 \%$ ), and breast pain (18.5\%). The mean treatment duration was significantly shorter in 14 patients who received directly observed therapy (DOT) compared with those $(\mathrm{n}=12)$ who did not $(6.7 \pm 1.7$ months vs. $8.5 \pm 1.6$ months, respectively; $p=0.01$ ). Seven patients underwent segmental mastektomy as complementary surgery. The highest rate of breast TB was seen in 2007 (37.1\% compared with 14.8\% between 2004 and 2006). Conclusions: Breast TB should be considered in patients with breast neoplasia, swelling, and discharge, and can be successfully treated by DOT with shorter treatment duration.

\section{Schlüsselwörter}

Brusttuberkulose · Poliklinik - DOT · Südosten der Türkei · Behandlung

\section{Zusammenfassung}

Hintergrund: Brusttuberkulose (TB) ist eine sehr seltene Form von TB. Fallreihen zu Brust-TB sind kaum vorhanden. Patienten und Methoden: Patienten mit Brust-TB, die in unserem Krankenhaus zwischen 2004 und 2008 behandelt wurden, wurden retrospektiv untersucht. Ergebnisse: Alle Patienten waren weiblich (medianes Alter $31,5 \pm 8,4$ Jahre). Mit Ausnahme einer Patientin handelte es sich um neue Fälle. Die Patientinnen wurden mit geschwollener Brust $(48,1 \%)$, Geschwülsten und Fluktuation (je 40,7\%) und Schmerzen in der Brust (18,5\%) vorstellig. Die mittlere Behandlungsdauer war signifikant kürzer bei 14 Patientinnen, die im Rahmen einer überwachten Therapie (directly observed therapy, DOT) behandelt wurden, verglichen mit denen $(n=12)$, die nicht auf diese Weise behandelt wurden $(6,7 \pm 1,7$ Monate bzw. 8,5 \pm 1,6 Monate; $p=0,01)$. Bei 7 Patientinnen wurde eine segmentale Resektion als ergänzende Maßnahme durchgeführt. Die höchste Brust-TB-Rate wurde 2007 verzeichnet $(37,1 \%$ verglichen mit 14,8\% zwischen 2004 und 2006). Schlussfolgerungen: Brust-TB sollte bei Patienten mit Umfangsvermehrungen, Schwellung und Sekretion aus der Brust in Erwägung gezogen werden. Brust-TB kann unter Einsatz der DOT-Strategie innerhalb eines kürzeren Zeitraums erfolgreich behandelt werden.

\section{KARGER}

Fax +497614520714

Information@Karger.de

www.karger.com (c) 2010 S. Karger GmbH, Freiburg 


\section{Introduction}

Breast tuberculosis (TB) was first defined by Sir Astley Cooper [1] in 1829 as a rare form of extrapulmonary TB. Breast TB is a very rare disease and constitutes only $0.025-1.04 \%$ of breast diseases [1-3]. It is more frequently encountered in developing countries in Africa and Asia where TB is common [4, 5]. In Turkey, breast TB is rarely seen. A limited number of case reports including very few patients have been published previously [69]. Papers on breast TB are generally in the form of case reports $[2,6,9]$. However, a number of reports have presented clinical features of larger patient groups for longer follow-up periods such as 13 cases in 10 years [5], 9 cases in 20 years [7], 52 cases in 15 years [10], and 20 cases in 13 years [11]. In the present study, we aimed to evaluate demographic data, diagnostic methods, therapeutic regimens, and duration of therapy in 27 breast TB patients treated at the Tuberculosis Control Dispensaries (TCDs) in Diyarbakir, Turkey over a period of 5 years.

\section{Patients and Methods}

Diyarbakir has 4 TCDs ( 2 located in the city center and 2 in adjacent towns) for the treatment and follow-up of all residents diagnosed with TB. The directly observed therapy (DOT) regimen was put into practice in Diyarbakir in June 2006. The chart records of the breast TB cases who were treated between January 2004 and December 2008 at these 4 TCDs were reviewed retrospectively. Demographic data such as age, gender, educational status, family and the patient's own TB history, complaints, and physical examination findings of the patients were recorded. In addition, postero-anterior (PA) chest radiographs for pulmonary TB and clinical and radiological findings of other TB forms were reviewed thoroughly. The breast TB diagnosis was made based on at least one positive result from biopsy, smear, or culture of breast discharge along with symptoms such as pain, mass, and swelling of the breast. The gold standard diagnostic tool for breast TB is bacteriological culture of breast tissue or Ziehl-Nielsen stain. However, in breast TB, bacilli are isolated in only $25.0 \%$ of cases, and acid-fast bacilli are identified in only $12.0 \%$ of the patients $[12,13]$. Therefore, demonstration of caseating granulomas in the breast tissue and involved lymph nodes may be sufficient for the diagnosis. Fine needle aspiration cytology (FNAC) is the most widely used initial invasive method for diagnosis of breast TB $[12,13]$. Breast TB regimens used in clinical practice are presented in table 1. The World Health Organization and several authors have recommend DOT at least during the initial phase of treatment for all patients in all countries, regardless of the level of development [14]

\section{Statistical Analysis}

Data relating to the duration of therapy and to whether DOT was administered were recorded with SPSS 10.0 (SPSS Inc., Chicago, IL, USA). Descriptive analyses and the Mann-Whitney U test were per- formed to detect differences between subgroups; $\mathrm{p}<0.05$ was accepted as statistically significant.

\section{Results}

All 27 cases were women, and their mean age was $31.5 \pm 8.4$ years. All of the women were housewives, except for 1 veterinarian (table 2). The patients' PA lung radiographs were assessed as normal by pulmonary diseases specialists. The patients had no respiratory symptoms. One of them had a history of contact to a TB patient, while the others had no history of contact to TB. One patient was evaluated as recurrent TB since she was diagnosed with breast TB following a previous TB lymphadenitis in the cervical region. The other patients had no TB history and were evaluated as new patients. The diagnosis was made by histopathological methods in all patients but one (table 2).
Table 2. Demographic and clinical data of the breast tuberculosis $(\mathrm{TB})$ patients $(\mathrm{n}=27)$

\begin{tabular}{|c|c|}
\hline & $\mathrm{n}(\%)$ \\
\hline \multicolumn{2}{|l|}{ Marital status } \\
\hline Single & $2(7.4)$ \\
\hline Married & $25(92.6)$ \\
\hline \multicolumn{2}{|l|}{ Education } \\
\hline Illiterate & $15(55.6)$ \\
\hline Literate + primary school & $8(29.6)$ \\
\hline High school & $2(7.4)$ \\
\hline University & $2(7.4)$ \\
\hline \multicolumn{2}{|l|}{ Involved part of the breast } \\
\hline Left & $12(44.0)$ \\
\hline Right & $11(40.0)$ \\
\hline Bilateral & $4(16.0)$ \\
\hline \multicolumn{2}{|l|}{ Signs in the breast } \\
\hline Swelling & $13(48.1)$ \\
\hline Fluctuation & $11(40.7)$ \\
\hline Mass & $11(40.7)$ \\
\hline Pain & $5(18.5)$ \\
\hline \multicolumn{2}{|l|}{ Method of diagnosis } \\
\hline Excisional biopsy & $22(81.4)$ \\
\hline Biopsy + smear positivity & $2(7.4)$ \\
\hline Fine needle aspiration & $2(7.4)$ \\
\hline Culture positivity & $1(3.8)$ \\
\hline \multicolumn{2}{|l|}{ Breast TB rates $2004-2008$} \\
\hline 2004 & $4(14.8)$ \\
\hline 2005 & $4(14.8)$ \\
\hline 2006 & $4(14.8)$ \\
\hline 2007 & $10(37.1)$ \\
\hline 2008 & $5(18.5)$ \\
\hline
\end{tabular}

Table 1. Breast TB treatment regimens $[12,20]$

\begin{tabular}{lll}
\hline Treatment time & Initial phase regimens & Continuation phase regimens \\
\hline 6 months & $\begin{array}{l}2 \text { months of isoniazid, rifampycine, pyrazinamide, } \\
\text { ethambutol or streptomycin }\end{array}$ & 4 months of isoniazid and rifampycine \\
9 months & $\begin{array}{l}2 \text { months of isoniazid, rifampycine, pyrazinamide, } \\
\text { ethambutol or streptomycin }\end{array}$ & 7 months of Isoniazid and rifampycine \\
\hline
\end{tabular}


Twentysix patients completed therapy with a full recovery. One patient was referred to another TCD. Our treatment success rate was $96.3 \%$. Fourteen patients received the DOT regimen for a mean duration of $6.7 \pm 1.7$ months; 12 patients did not receive the DOT regimen and were treated with classic anti-TB treatment for a mean duration of $8.5 \pm 1.6$ months. This difference was statistically significant $(p=0.01)$. In both groups, therapy resulted in recovery. However, the mean treatment duration of the DOT regimen group was significantly shorter compared with the classic regimen group $(\mathrm{p}=$ 0.01 ). Additionally, segmental resection was performed in 7 patients $(25.9 \%)$, abscess drainage in 5 patients $(18.5 \%)$, and subtotal resection in 2 patients $(7.4 \%)$ as complementary surgical procedures. Breast TB rates were $14.8 \%$ in 2004, 2005 and $2006 ; 18.5 \%$ in 2008 and $37.1 \%$ in 2008 . The disease occurred more frequently in 2007.

Sonography was carried out in 20 patients, showing a defined breast mass in 15 patients $(55.6 \%)$, defined ipsilateral axillary lymph node involvement in 10 patients $(37.1 \%)$, defined non-specific findings in 5 patients $(18.5 \%)$ including hypoechoic masses, internal echoes, and irregular borders, and bilateral axillary lymph node involvement in 1 patient $(3.7 \%)$. Mammography was performed in 8 patients $(29.6 \%)$, showing non-specific stromal coarsening in 6 patients $(22.2 \%)$, and skin thickening with sinus tracts communicating with the intramammary masses in 2 patients $(7.4 \%)$.

In $2005,257(33.0 \%)$ of 424 new TB cases were extrapulmonary $\mathrm{TB}$, and $0.94 \%$ of $\mathrm{TB}$ patients were breast $\mathrm{TB}$. In 2007, 377 new TB cases were diagnosed in Diyarbakir, 174 $(46.2 \%)$ of them were extrapulmonary TB. Of the identified TB cases, $2.7 \%$ were breast TB. In 2008, 318 new TB cases were determined, and $115(36.2 \%)$ of them were extrapulmonary TB; $1.6 \%$ of TB cases were breast TB. Hence, between 2005 and 2008, extrapulmonary TB cases formed approximately $30.0 \%$ of all TB cases in Turkey [15]. In our province, this rate was $38.8 \%$ and above the overall Turkish rate.

Breast involvement was nearly equal in the left and right breasts (44.0 vs. $40.0 \%)$. Disease signs and symptoms were swelling (48.1\%), mass and fluctuation $(40.7 \%)$, and pain (18.5\%). The most frequently used diagnostic tool was excisional biopsy $(81.4 \%)$, followed by biopsy plus acid-fast bacilli smear $(7.4 \%)$, FNAC (7.4\%), and positive TB culture $(3.8 \%)$ (table 2).

\section{Discussion}

Breast tissue is notably resistant to TB. This is owing to the fact that, like skeletal muscles and spleen, it is an inconvenient environment for the survival and multiplication of tubercle bacilli [16]. Breast TB is a rare extrapulmonary presentation of $\mathrm{TB}$, accounting for less than $1.0 \%$ of all diseases of the breast in the industrialized world $[9,15,17]$. The incidence of the disease is higher in countries endemic for TB, like the
Indian subcontinent, where it may be as high as $4.0 \%$ [17]. TB of the breast is classified as primary and secondary; primary when no other foci of TB are detectable, and secondary when there are other foci of TB at other locations in the body [18]. In one study [11], only 1 of 20 cases with breast TB had a history of previous pulmonary TB. In another study [10], 21 of 52 breast TB cases had axillary lymphadenopathy, and 5 had previous pulmonary TB. In our study, none of the patients had a previous history of pulmonary TB, but 1 patient had had previous TB lymphadenitis in the cervical region. The other patients had no history of TB. Thus, 26 of our patients were accepted as primary breast TB.

Approximately $73.0 \%$ of cases of breast TB can be diagnosed by FNAC. An excisional biopsy is strongly advocated; differential diagnoses such as sarcoidosis, fungal infections, ductular ectasia, and a coexisting malignancy should be ruled out [12]. In most of our patients, the main differential diagnosis was breast cancer due to the reported high incidence of breast cancer in open biopsy specimens. However, histological examination of our biopsy specimens revealed no breast cancer diagnosis. Khanna et al. [10] diagnosed 52 breast TB cases by FNAC and histological methods with a rate of $100.0 \%$. We also diagnosed all patients histologically, except for 1 patient diagnosed by TB culture.

In breast $\mathrm{TB}$, the presenting signs and symptoms tend to be breast masses and an open wound accompanied by discharge $[9,10,19]$. In our study, breast masses were the most frequent examination finding. In the majority of patients, the initial complaint was swelling of the breast. Breast TB generally affects women of reproductive age $[10,11,19]$. The mean age of the patient was in parallel with the data in the literature, and most of our patients were married. One third of breast TB patients have ipsilateral axillary lymph node involvement $[12,20]$. Our results were similar to those in the existing literature. Breast involvement was reported as mostly in the right breast [11, 19] or as equal on both sides [10]. In our patients, the rate of involvement of the right and left side was very similar with a slight dominance of the left breast.

The DOT regimen was introduced in our province in 2006. The rate of extrapulmonary TB in our province was higher compared with the overall national rate. In addition, after introduction of the DOT regimen, the number of extrapulmonary TB cases increased in the city.

Partial or general surgical therapeutic options can be used in particular situations, such as the presence of masses and abscesses; options include simple or segmental mastectomy or drainage of abscess [21]. Therapeutic guidelines remark that anti-TB therapy given for 6 months is sufficient [20, 22]. However, in some series, this therapy was administered in a different manner. For example, Khanna et al. [10] treated 52 patients with breast TB for a mean duration of 9 months, and they extended this period to $12-18$ months in 18 patients. In another study [19], one third of the patients were given a 9-month therapy. But in a different study [11], the standard 
6-month therapy was sufficient for all patients to recover. In our study group, only $48.1 \%$ of the patients were given therapy via the DOT regimen for 6 months, the others implemented therapy by themselves for a prolonged period. However, no difference was observed between the 2 groups in terms of the period of improvement of complaints and findings on examination. The DOT regimen can prevent unnecessarily prolonged therapy and possible adverse effects of antiTB drugs, and ensures successful completion of therapy in a shorter period of time. We believe that DOT, which is certainly suggested for smear-positive pulmonary TB cases, may increase success rates in the treatment of extrapulmonary $\mathrm{TB}$ forms including breast TB.

One limitation of the present study is its retrospective nature which made it impossible to investigate known risk fac- tors for breast TB, including multiparity, lactation, trauma, history of suppurative mastitis, and acquired immune deficiency syndrome (AIDS). In conclusion, breast TB is a rare entity among extrapulmonary TB forms and hardly encountered in clinical practice. It is important to recognize the initial signs and symptoms of the disease. Standard anti-TB therapy should be given as in other TB forms. There are different therapeutic approaches, and the DOT regimen can be helpful in the treatment of breast TB. Further clinical studies with more patients are needed to highlight this issue.

\section{Conflict of Interest}

All authors in this paper have no financial or personal conflicts of interest to disclose.

\section{References}

1 Cooper A: Illustration of the Diseases of the Breast. Part I. London, Longman, Rees, Orme, Brown and Green, 1829, p. 7.

2 Sharma PK, Babel AL, Yadav SS: Tuberculosis of the breast (study of 7 cases). J Postgrad Med 1991;37:24-6.

3 Bani-Hani KE, Yaghan RJ, Matalka II, Mazahreh TS: Tuberculosis mastitis: a disease not to be forgotten. Int J Tuberc Lung Dis 2005;9:920-5.

$\checkmark 4$ Göksoy E, Düren M, Durgun V, Uygun N: Tuberculosis of the breast. Eur J Surg 1995;161:471-3.

$\checkmark 5$ Al-Marri MR, Almosleh A, Almoslmani Y: Primary tuberculosis of the breast in Qatar: ten year experience and review of the literature. Eur J Surg 2000; 166:687-90.

6 Akkaya E, Karagöz T, Yıldız A: Meme tüberkülozu (3 olgu). SSK Tepecik Hastanesi Dergisi 1992;2: 64-8.

7 Göksoy E: Tuberculosis of the breast. Eur J Surg 1999;161:471-3.

8 Yazıcıoğlu S, Coşkunsel M, Coşkunsel N: Meme tüberkülozu. Tüberküloz ve Toraks 1979;27:20610.
9 Kalaç N, Ozkan B, Bayiz H, Dursun AB, Demirağ F: Breast tuberculosis. Breast 2002;11:346-9.

10 Khanna R, Prasanna GV, Gupta P, Kumar M, Khanna S, Khanna AK: Mammary tuberculosis: report on 52 cases. Postgrad Med J 2002;78:422-4.

11 Da Silva BB, Lopes-Costa PV, Pires CG, PereiraFilho JD, Dos Santos AR: Tuberculosis of the breast: analysis of 20 cases and a literature review. Trans R Soc Trop Med Hyg 2009;103:559-63.

12 Baharoon S: Tuberculosis of the breast. Ann Thorac Med 2008;3:110-4.

13 Martinez-Parra D, Nevado-Santos M, MelendezGuerrero B, Garcva-Solano J, Hierro-Guilmain CC, Prrez-Guillermo M: Utility of fine needle aspiration in the diagnosis of granulomatous lesions of the breast. Diagn Cytopathol 1997;17:108-14.

14 Iseman MD, Cohn DL, Sbarbaro JA: Directly observed treatment of tuberculosis - we can't afford not to try it. N Engl J Med 1993;328:576-8.

15 Harris SH, Khan MA, Khan R, Haque F, Syed A, Ansari MM: Mammary tuberculosis: analysis of thirty-eight patients. ANZ J Surg 2006;76:234-7.
16 Mukerjee P, George M, Maheshwari HB, Rao CP: Tuberculosis of the breast. J Indian Med Assoc 1974;62:410-2.

17 Tse GM, Poon CS, Ramachandram K, Ma TK, Pang LM, Law BK: Granulomatous mastitis: a clinicopathological review of 26 cases. Pathology 2004;36:254-7.

18 Mckeown KC, Wilkinson KW: Tuberculous diseases of breast. Br J Surg 1952;39:420.

19 Harris SH, Khan MA, Khan R, Haque F, Syed A, Ansari MM: Mammary tuberculosis: analysis of thirty-eight patients. ANZ J Surg 2006;76:234-7.

20 Jalali U, Rasul S, Khan A, Baig N, Khan A, Akhter R: Tuberculous mastitis. J Coll Physicians Surg Pak 2005;15:234-7.

21 Luh S, Hsu JD, Lai YS, Chen SW: Primary tuberculous infection of breast: experiences of surgical resection for aged patients and review of literature. J Zhejiang Univ Sci B 2007;8:580-3.

22 Elmrabet F, Ferhati D, Amenssag L, Kharbach A, Chaoui A: Breast tuberculosis. Med Trop (Mars) 2002;62:77-80. 